\title{
The Comparision of Classical Ethical Theories in Ancient Greece Philosophy and Islamic Philosophy: The Example of Aristotle and Ibn Miskavayh, Tusi and Kinalizade
}

\author{
Emine ÖZTÜRK \\ Prof. Dr., Kafkas University, Theology Faculty, \\ Department of Philosophy and Religious Sciences
}

\section{Abstract}

In this study, I will make an analysis of the comparision of classical ethical theories in Ancient Greece Philosophy and Islamic Philosophy. The analysis of the comparision of classical ethical theories in Ancient Greece Philosophy and Islamic Philosophy depends on three philosophical and psychological concepts. These concepts are first of all, the thought in other words the ability of thinking, secondly the desire, in other words the ability of desire, as Freud said libido, and thirdly agression the ability of anger. These three abilities in one person reveals one virtue in society, this virtue is the virtue of justice. And this study will tells about how we can reveal the virtue of justice in one society by applying these three abilities and virtues in one person. Because these abilties corresponds three virtues in classical ethics. These three virtues are thinking, chastity and courage. And this study will analyze the thinking, chastity and courage in Ancient Greece Philosophy and Islamic Philosophy.

Keywords: comparison, classical ethics, theories, ancient Greece philosophy, Islamic philosophy

\section{Introduction}

The first work written on social ethics in the history of philosophy is the following three works of Aristotle. Ethics for Nikhomakos, Ethics for Eudemos and Magna Moralia. In this text, it is certainly not thought to explain the life of Aristotle, which everyone and especially European scientists, who are the platform where this text is presented, well known. However, it is planned to include Arsito's views, especially on virtue ethics, here. Because, despite the abundance of moral schools in the philosophical sense in the West, the only moral school that comes to mind when Philosophical Islamic Moral is mentioned in the east is the morality of virtue. And the first and the only work written in the field of Philosophical Islamic Morality in the Islamic world is Ibn Miskavayh's work titled Tahzibu'l-Ahlak, namely the Beautification of Morals. And this work is a work written in the field of virtue ethics. 
Apart from this work, it is the work of Ibn Miskavayh named Tartibu's-Saadat and Manazilu'l-Ulum. This work has been translated into Turkish under the name Happiness and Philosophy. And this work is a work on virtue ethics. And the other work which is written after Ibn Miskavayh's works Nasirduddin Tusi's work named Ethics of Nasıri. And the last work which is wirtten about virtue ethics is the Highest Morality in Turkish named Ahlak-1 Alai.

Let's have a look what is ethics and morality. In the Turkish Language Association's Grand Dictionary, morality is defined as "the forms of behavior and rules that people must obey in a society."

"Morality is the plural of the Arabic word "hulk". In Islamic sources, "hulk" and morality are used in the same sense. "Hulk" is often used to describe the human being as a whole, together with the word "halk" meaning creation. "Hulk" belongs to the inner/psychological properties of man, and the people to the outer / physiological aspect of man. "Such man's halk and hulk are beautiful." means that such man's the inner/spirit and apparent/appearance are beautiful." Our studies on the concept of morality show that the definitions of the concept of morality, as a term that has received intense interest from humanities and social sciences, can be grouped into three main groups. sweating. The first group is the definition of the concept of morality in similar meanings with the human behavior, lifestyle and character or temperament expressing the internal processes related to these behaviors. The second group morals; They defined it by referring to a framework of meaning in which concepts such as external principles, measures or social norms make up human behaviors or control their behavior. The definitions in the third group are moral; It has been treated as a science or art with both theoretical and practical dimensions carried out with the aim of describing or improving / developing on the individual and social dimensions specified in the first two definitions.

a) Morality in terms of human character structure and actions:

Morality is the situation that enables the soul to reveal its own actions without thinking and thinking about it. This situation occurs in two ways. The first is the natural morality stemming from temperament such as being quick to anger and fear; the second one, while at the beginning is by thinking and moving, it gradually becomes a habit." (Ibn Miskavayh, 2018, 51.)

b) Morality as a social product that directs human behavior:

Morality is a set of rules that reveal how these values are to be kept alive and how to achieve these goals with a set of values and purposes accepted, determined and defined within a cultural environment, or a certain kind of belief, order, prohibition, norm of a human community during a certain historical period. and it can be defined as a traditional life style that is organized according to values and depending on the regulation in question. (Cevizci, 2002: 3) 
c) Morality as a science or art that seeks to examine and develop human character and actions and social rules:

There is a science of morality that examines moral events. This science is often expressed briefly with the word morality. Morality is the science of the ideal laws (rules) that govern human movements and the art of adapting them to the various situations of life in the best way. The purpose of ideal laws is not how people act, but how they should act. He wants them to be like this or that according to a purpose. (Pazarll, 1980: 11-15)

As a result, a definition can be made that includes all dimensions of the concept of morality, "the social rules that guide human actions and the character structure that derives from these actions; actions and their evaluations about them; the concept that simultaneously expresses the theoretical and practical field that deals with human volition." (Kaymakcan \& Meydan, 2014: 19)

Lets's have a look about ethics phenomenon. "As a social being, man personally experiences morality. When he not only lives with morality, but begins to think about the concepts of morality and to express his thoughts, he transcends morality and enters the path of ethics. It is a factual and historically experienced thing, a certain practice of morality and morality; We can say that ethics is the theory of the practice in question, the philosophy of morality. Or, in other words, we can define ethics as the discipline of moral principles or philosophical discipline, which is the subject of value, the way of thinking that includes everything that adds meaning to life." (Cevizci, 2002: 4)

Three different ethical approaches / types are mentioned according to the way they handle morality. These are descriptive, normative and meta-ethics.

"1-Descriptive ethics; morality emerged as a result of the application of the scientific approach to the field of morality. Descriptive ethics defines the consequences of actions by simply observing human actions rather than declaring or determining rules. It is concerned with the moral facts that exist, not the morality that should be.

2-Normative ethics; investigates the moral principles that inform how we should live, discuss what the highest and most valuable things in life are, consider what elements a just society should include, and question what makes a person good morally. Normative ethics is an area of ethics that aims to guide the correct attitude, behavior and action patterns and policies at individual, social and universal levels. What is right and what is wrong, what are the moral standards that regulate our behavior, what character and character we should have, what moral duties we have to do are the main areas of inquiry.

3-Meta-ethics, is the reflection of contemporary analytical philosophy in the field of ethics. He says that the moral philosopher has no responsibility to set norms or give lines, nor have the power to tell people how to be happy. Those who deal with ethics with the meta-ethical approach talk about and analyze the moral concepts and 
judgments set by normative ethics. To talk about morality in a kind of meta-ethics is to look at the notion of morality from the top and the outside." (Cevizci, 2002: 6-11)

Apart from these basic concepts, there is also an external and internal morality. Now let's have look to these two concepts.

"Ethics or morality is subjected to the distinction between internal / internal and external / external, depending on whether the basic motive leading the individual to moral behavior is derived from values internalized or external to himself. External morality forces the individual to discipline and accept his own values with a feeling of fear, love and authority. It expects obedience from him. Love and authority are essential in inner submission. Fear gets out of the way completely, instead understanding remains. The social function and the inner / inner - controlled understanding, which expresses the individual to put his own intent and goal instead of the moral understanding that prioritizes the understanding of benefit, is deemed a true moral understanding and is considered more valid. The main purpose of the child's socialization is to provide self-management, to reach internal morality from external morality, instead of being governed by external factors. Values education is the process of supporting the individual to acquire moral character traits consisting of values that have turned into virtues in order to achieve this inner obedience." (Kaymakcan \& Meydan, 2014: 23)

"Unlike the use of the concept of value that goes beyond the moral field and personality, virtue and virtue are perceived as concepts related to morality and character, which is the moral aspect of the individual's personality. Values internalized by the individual, worthy of human dignity, often socially and religiously approved, are accepted as virtues.Let's also look at the concept of virtue. In order for a state to be virtue / virtue, it must be well established in the soul. In this sense, being virtuous and being moral are the same. This is the fact that the verbs come from the self without the need for long thinking and any force. For example, who occasionally helps someone else by forcing himself. Even if someone has acted generously, they are not considered to have the virtue of generosity. All virtues are established predispositions." (Kaymakcan \& Meydan, 2014: 27)

"Virtue and virtuous -often used interchangeably- have become one of the most important concepts of practical morality, with the views and practices put forward for both theoretical and moral education, especially in the context of individual morality, starting from Socrates, Plato and Aristotle and reaching the present day through Islamic moralists. According to Socrates, the ways to reach happiness, which is the purpose of life, are the virtues of competence states that make up the personality. Accordingly, human competence that contributes to the realization of the purpose of life is virtue. Virtue is equivalent to knowledge. According to Plato, nothing in the world is futile and haphazard, and there is a function that every living and nonliving being has to replace. Virtue is the state of something that occurs when a being or an organism performs its own proper function, fulfilling its own task properly. For 
human beings, there are three different virtues arising from the fact that the soul fulfills the functions of three different aspects of the soul / soul in a balanced manner. The virtue of the appetite function is proportionality, the courage of the will function, and the virtue of the thinking function is wisdom." (Cevizci, 2002: 33-73)

In this study, I will make an analysis of the comparision of classical ethical theories in Ancient Greece Philosophy and Islamic Philosophy. The analysis of the comparision of classical ethical theories in Ancient Greece Philosophy and Islamic Philosophy depends on three philosophical and psychological concepts. These concepts are first of all, the thought in other words the ability of thinking, secondly the desire, in other words the ability of desire, as Freud said libido, and thirdly agression the ability of anger. These three abilities in one person reveals one virtue in society, this virtue is the virtue of justice. And this study will tells about how we can reveal the virtue of justice in one society by applying these three abilities and virtues in one person. Because these abilties corresponds three virtues in classical ethics. These three virtues are thinking, chastity and courage. And this study will analyze the thinking, chastity and courage in Ancient Greece Philosophy and Islamic Philosophy.

Let's have a comparative look between these four writers thoughts and books.

"Fist of all let's have a look to Ethics for Nicomachus (Nicomachus's Morality), which is considered to be the most important foreign resource affecting Islamic Moral Thought; It consists of ten books that deal with virtue, evil, happiness, pleasure and what must be done in order to gain real good and virtue and keep it alive in society. At the beginning of the book, Aristotle states that he researches what is good for man through morality and- depending on him - politics. He states that his work aims not only to find out how to achieve the best of a single person but all people living in the city, and that this goal and effort is divine." (Kaymakcan \& Meydan, 2014: 48)

The First Book, which questions what the real good is, begins with the statements that 'every action and choice desires a good: Therefore they appropriately articulated the good as the thing that all desires' (Aristotle, 2019: 42) and concludes that the ultimate good is the happiness that comes from behavior in accordance with the perpetual virtue. (Aristotle, 2019: 42)

The subject of the second book is what is the virtue that will lead to happiness when followed constantly. When Aristotle began the chapter to question what virtue was, he actually made his decision. Therefore, "There are two types of virtues, one is the virtue of thought and the other is the virtue of character ... The virtue of thought is formed and develops more with education, therefore it requires experience and time; the virtue of character is acquired by habit ..." (Aristotle, 2019: 90). He regards being a middle ground, the traits that enable them to do the actions that constitute them, and the commands of the right mind, acquired willingly. (Aristotle, 2019)

In the third book, it is discussed whether viciousness done due to coercion or ignorance can be regarded as virtue or goodness done in this way and the virtues of 
valor and proportionality. It is a forced structuring, the beginning of which is outside of the doer or the exposed person, and therefore without any share of the doer or the exposed person. (Aristotle, 2019: 127-175)

In the fourth book, the virtue of generosity, which is the middle of stinginess and extravagance, the virtue of splendor, which is the middle of stinginess and sternness, and the virtues of self-confidence, which is the middle of self-righteousness; The fifth book deals with the virtues of justice and righteousness. According to him, all virtues exist together in justice. Justice is the most important virtue that carries its own purpose. Justice is not a part of virtue, it is the totality of virtue; the opposite of injustice is not a part of evil, but the totality of evil. (Aristotle, 2019: 176-278)

The sixth book is devoted to questioning what is the right mind, in which virtue is realized by its own choice. Sanity and wisdom, which are basic thought virtues, are also examined under this title. Therefore, the right mind that leads to virtue is acquired by making decisions with common sense and wisdom. (Aristotle, 2019: 279319)

In the seventh book, the three vices to be avoided: the concepts of evil, self-control, monstrosity, and pleasure and pain; in the eighth and ninth book, the issue of friendship is discussed. (Aristotle, 2019: 320-477)

The tenth book deals with the issue of enjoyment and the effect of youth education and education being permanent through law. In this chapter, politics is presented as a science that complements education, as a kind of science to accustom citizens to virtuous behavior. (Aristotle, 2019: 477-532)

Ibn Miskavayh (d. 1030), who was named "the greatest author of morality in Islam" by Macit Fahri ${ }^{1}$ and accepted as the author of the first ethics book in his own right, became famous as Tahzibu'l Ahlak (Improving Morality). The name of the work found is Taharetu'l A'rak (Purification of Temperaments). (Fahri, $2004: 21$ )

Tahzibu'l Ahlak (Improving Morality), which is the first work that comes to mind when morality is mentioned in Islam, is the first systematic work in the history of Islamic thought that deals with the main subjects of morality. In his work, the author significantly benefited from ancient Greek philosophy, especially Aristotle's Ethics for Nicomachus, but he adhered to Islamic thought in fundamental issues such as human nature, religion-moral relationship, child education and the highest purpose of morality. (Ibn Miskavayh, 2018: 21-50)

In the work, while emphasizing the virtues and the importance of reason in discovering them and overcoming the deceptions of the soul, there is a mystical point of view on the ways of making virtue into a habit and making the soul devilish. In a way it is; He tried to blend the mystical ethics of Islam with the philosophical moral understanding of some Greek philosophers, especially Aristotle, by melting them into 
the pot of Islamic philosophy. There are some who attribute the wide impact of the work to Ibn Miskeveyh's success in presenting the views of ancient Greek philosophers in harmony with the moral understanding of the basic sources of Islam.

The author explains the purpose of writing the book as reaching a character that will ensure that all our behavior is good, but easy, simple and effortless, and to find a method that will achieve this morality. (Ibn Miskavayh, 2018: 17) The book consists of seven chapters, after a brief introduction in which the purpose of the writing is explained. In the first chapter, the human soul is defined in detail; in the second part, the concepts of morality and character are discussed; the third part deals with the difference between well-being and happiness; in the fourth chapter, under the title of human verbs, basic virtues are examined in terms of verbs that are similar to virtue in appearance but are not virtue; in the fifth chapter, types of love, divine love and friendship; In the sixth chapter, the diseases of the soul and in the seventh chapter, the treatment methods of the diseases of the soul are discussed. (Ibn Miskavayh, 2018: 21-263)

The author, who states that the human soul consists of the abilities of thinking, desire and anger, seems to be that the thinking faculty of these three faculties of the soul must dominate the others in order to reach the moral character. If the desiring or angry faculties do not obey the thinking ability, there is no difference in terms of fate between knowing the truth but losing it to the soul and deliberately doing wrong. As the author puts it, "A person who sees with a blind who falls into a well - although the former is excused in his case - are the same in terms of being in danger. This is the case of a person who knows the wrong, and the person who knows the truth but cannot afford himself." (Ibn Miskavayh, 2018: 21-50)

One should not allow the desiring and angry soul to overcome the thinking self, and should be strong when he feels such a struggle in his soul. Due to laziness, looseness and not taking a lot of trouble, Bahla should not fall, if he is eaten and regrets he should follow his regret.

Ibn Miskeveyh's justification and classification of virtues is based on the trinity division from the Ancient Greek philosopher Plato. (Plato, 2005:153) In this division, virtues are based on each of the three faculties of the soul: wisdom for the ability to think (reason), bravery to anger (gadap), and chastity to lust (desire). When these faculties act in harmony, the fourth virtue, justice, emerges. These main virtues also have sub-virtues. The sub-virtues of wisdom are intelligence, memory, reasoning, quick understanding, clarity of mind, correct judgment and easy learning; The lower virtues of courage are generosity, courage, steadfastness, perseverance, perseverance, self-confidence, courage, and tolerance of boredom. The lower virtues of chastity are shame, tranquility, patience, generosity, freedom, blood thrills, gentleness, regularity, good mood, peace-loving, dignity and avoidance of evil. The sub-virtues of justice are friendship, greatness, maintaining relationships with 
relatives, rewarding, treating well, doing something beautifully, grace and piety. (Plato, 2005:153)

A large part of Tehzib is beautifying habits; It is about the upbringing in which the different parts and faculties of the soul will be harmonized and directed towards the main goal of human actions, namely happiness. This discipline is named as protecting the health of the soul in relation to medicine. In order to protect his moral health, one should take care not to arouse the pleasurable things that he tastes, he should carefully take into account his own faults, make friends who will openly tell him his faults, and struggle to cleanse himself from the traits that are regarded as disgrace compared to the virtues and the bad deeds such as anger and cowardice. The author, who works richly on the issue of recognizing one's own flaws, relating to friendship and quoting Galinos; he concludes his work with praise and salawat after the statements of Socrates, which emphasize that in order to attain calmness and joy, we should not value world wealth.

The other big writer of ethics in Islamic Literature is Nasiruddin at-Tusi. The work named Ahlak-ı Nasıri by the Khorasan scholar Nasirudin Tusi (d. 672/1274), who has studies on mathematics, astronomy, medicine, philosophy and exquisite science (psychology), is one of the important touchestones of Islamic moral thought in terms of its characteristics and its effect on the latter. is one of The idea of writing the book was formed by the request of a translation of this work into Persian during the discussion of the outstanding and competent philosopher Ibn Miskavayh Tahare (Tehzibü'l Ahlak) while in the service of the Governor of Kuhistan, Nasiruddin Abdurrahim Ibn Abi Mansur. The author states that the exact translation of the work is requested, but he thinks that this will not be sufficient to reflect the real and beautiful meanings of the work, and that the science of housekeeping and politics, which are not included in this work, should be included among the subjects of the science of ethics, and he wrote that work in a different style. (Nasiruddin at-Tusi, 2016 :25-341)

The book will be classified as "Tahzi'bu'l Ahlak (Moral Education)”, "Tedbir-i Menazil (Home Management)", "Siyaset-i Müdün (State Administration)", three main articles and thirty chapters. The first article deals with theoretical morality and individual morality, largely in the extended translation style of Ibn Miskeveyh's Arabic work Tahzibu'l Ahlak. The second part is devoted to family ethics and the third to the issues of city administration and social morality. In the second chapter, from Ibn Sina's treatise, Tedribü'l Menazil, in the third chapter, Farabi's views on politics and social morality are greatly benefited. Although the work is not original as it was written with extensive use of various sources written before it, it is considered important with its descriptions, arrangement and concise content. (Nasiruddin at-Tusi, 2016)

The fouth book in Islamic Literature is Kinalizada Ali Efendi's book named Ahlak-ı Alai (The Highest Morality). "Kinalizada Ali Efendi was born in Isparta in 1510 and died in Edirne in 1572. Coming from a cultured family, after completing his first education in 
Isparta, he studied at various level madrasas in Istanbul and the Sahn-1 Seman Madrasah in Fatih. After working as a professor in madrasas in Edirne, Bursa, Kütahya and Istanbul for more than twenty years, he was appointed to Damascus judge and wrote his famous moral work while he was in this post. In the following periods, he worked as the judges of Bursa, Edime and Istanbul in Aleppo and rose up to the Anatolian Kazasker." (Kinalizada Ali Efendi, 2017: 1-18)

Kınalızade Ali Efendi's Ahlak-ı Alai; It is an ethics book that Ibn Miskeveyh started as Arabic and completed the peak of Islamic moral thought developed by Tusi in Persian. It was written with the idea of creating a Turkish work in accordance with these by making use of the works of Persian Ahlak-ı Devvani, Ahlak-ı Nasıri, partly Ahlak-1 Muhsini and the works of the Arabic era Tahzibü'l Ahlak and Ghazali, who were famous before him. Through these ethics books that he made use of, Aristotle's Ethics for Nicomachus also has the effect. Ahlak-1 Alai is a work created by benefiting from the ideas of all the famous representatives of the traditionalist, philosophical and mystical schools of Islamic morality, and gained fame in its field with its language, style, method and arrangement.

The work begins with a broad preoccupation about the spirit, the soul and the innate characteristics of man. The first chapter, titled the science of morality, is devoted to theoretical and functional ethics. In this section, the science of morality, purification of the soul, virtues and disgrace, four basic virtues and sub-virtues; verse, hadith, couplet and so on. It is explained using. Kinalızade accepts four wisdom as wisdom, courage, chastity and justice in accordance with the moralists before him. He assigns sub-virtues to these four virtues by adhering to Nasiruddin Tusi. The definition of virtue also depends on tradition: Virtue is mediocre and moderate. Disgrace, on the other hand, is to go out of moderation and deviate from extremism and tefrit. If justice is subjected to persecution, its interpretation is to consent to being persecuted. It is disgrace to persecute someone else, and consenting to persecuting oneself is a resignation. Diseases of the soul that drive people to disaster are unnecessary fear; excessive eating and drinking and cravings; hear the sadness of unreachable requests; envy; It is hypocrisy and illnesses of the language such as dealing with empty things, curse, malice, backbiting and supposed non-stop. Fear of death or other inevitable things prevents the fulfillment of the right and the achievement of good. However, if the feared situation is inevitable, fear does not help it. The important thing is to brace him with steadfastness. Unnecessary worrying about a manageable situation will fail us in vain. So in any case, excessive fear is unnecessary. (Kinalizada Ali Efendi, 2017: 21-316)

The second part of the work is devoted to topics related to family morality, and the third to social ethics. In the family ethics section, the characteristics of the kindergarten, the duties of the family head, and the responsibilities of family members to each other are explained. Kinalizade; After stating that the house should be built in a way that is far from being pretentious, simple but sufficient enough to 
meet the needs of the family, it attaches special importance to the fact that neighbors are righteous and benign people in house selection. He advises to avoid the neighbors of the evil, cruel and ignorant. (Kinalizada Ali Efendi, 2017: 317-468)

While Kinalizade criticizes polygamy, he defends the importance of monogamy for a good family life, religious education for children and the need to teach girls to read and write. In the third chapter, which includes ethics related to society, politics and business life, he investigates the moral conditions of a virtuous city in accordance with the tradition of Farabi. It attaches special importance to the knowledge and virtue of statesmen in the administration of the country, and to compassion and justice in the administrative procedure of the country. (Kinalizada Ali Efendi, 2017: 471- 522)

\section{Conclusion}

Thess four writers divide the virtues to three parts. The division of virtues are based on each of the three faculties of the soul: wisdom for the ability to think (reason), bravery to anger (gadap), and chastity to lust (desire). When these faculties act in harmony, the fourth virtue, justice, emerges. These main virtues also have subvirtues. The sub-virtues of wisdom are intelligence, memory, reasoning, quick understanding, clarity of mind, correct judgment and easy learning; The lower virtues of courage are generosity, courage, steadfastness, perseverance, perseverance, selfconfidence, courage, and tolerance of boredom. The lower virtues of chastity are shame, tranquility, patience, generosity, freedom, blood thrills, gentleness, regularity, good mood, peace-loving, dignity and avoidance of evil. The sub-virtues of justice are friendship, greatness, maintaining relationships with relatives, rewarding, treating well, doing something beautifully, grace and piety.

Let's have a short and quick look to these four book's and four writer's division of virtues.

\begin{tabular}{|l|l|l|l|l|}
\hline \multicolumn{2}{|c|}{ VIRTUES AND SUB-VIRTUES ACCORDING TO ISLAMIC MORALISTS AND ARISTOTLE } \\
\hline $\begin{array}{l}\text { BASIC } \\
\text { VIRTUES }\end{array}$ & $\begin{array}{l}\text { ACCORDING } \\
\text { TO VITALS } \\
\text { ARISTOTLE }\end{array}$ & $\begin{array}{l}\text { ACCORDING } \\
\text { TO IBN } \\
\text { MISKAVAYH }\end{array}$ & $\begin{array}{l}\text { ACCORDING TO } \\
\text { NASIRUDDIN } \\
\text { TUSI }\end{array}$ & $\begin{array}{l}\text { ACCORDING } \\
\text { TO } \\
\text { KINALIZADE } \\
\text { ALI }\end{array}$ \\
\hline $\begin{array}{l}\text { PHILOSOPH } \\
\text { Y }\end{array}$ & $\begin{array}{l}\text { Wisdom is a } \\
\text { result of the } \\
\text { virtue of } \\
\text { thought. It } \\
\text { occurs with } \\
\text { more } \\
\text { education. }\end{array}$ & $\begin{array}{l}\text { Intelligence, } \\
\text { remembering, } \\
\text { thinking, } \\
\text { quick } \\
\text { understanding, } \\
\text { understanding } \\
\text { strength, open } \\
\text { mind } \\
\text { and easy }\end{array}$ & $\begin{array}{l}\text { Intelligence, } \\
\text { quick } \\
\text { understanding, } \\
\text { mind } \\
\text { clarity, ease of } \\
\text { learning, } \\
\text { good thinking, } \\
\text { letention in } \\
\text { memory } \\
\text { (memory), }\end{array}$ & $\begin{array}{l}\text { Intelligence, } \\
\text { quick } \\
\text { understandin } \\
\text { g, } \\
\text { clarity of } \\
\text { mind, easy } \\
\text { learning, } \\
\text { thinking right, } \\
\text { honing and } \\
\text { thinking. }\end{array}$ \\
\hline
\end{tabular}




\begin{tabular}{|c|c|c|c|c|}
\hline & & & $\begin{array}{l}\text { recall } \\
\text { (contemplation } \\
\text { ). }\end{array}$ & \\
\hline CHASTITY & $\begin{array}{l}\text { It is a result } \\
\text { of character } \\
\text { virtue. It is } \\
\text { won by habit. } \\
\text { Validity of } \\
\text { valor and } \\
\text { moderation } \\
\text { are among } \\
\text { them. }\end{array}$ & $\begin{array}{l}\text { Feeling of } \\
\text { embarrassmen } \\
\text { t, calmness, } \\
\text { patience, } \\
\text { generosity, free } \\
\text { don't be } \\
\text { content, soft } \\
\text { disposition, } \\
\text { regularity, } \\
\text { good } \\
\text { mood, } \\
\text { peacemaking, } \\
\text { heavy } \\
\text { of headlines } \\
\text { and evils } \\
\text { avoidance. }\end{array}$ & $\begin{array}{l}\text { Mildness, good } \\
\text { trajectory } \\
\text { (self- } \\
\text { authorization } \\
\text { effort), at peace } \\
\text { with itself } \\
\text { being, peace, } \\
\text { patience, faith, } \\
\text { dignity } \\
\text { (dignity), } \\
\text { avoidance } \\
\text { (vera), } \\
\text { regularity, } \\
\text { freedom and } \\
\text { generosity. }\end{array}$ & $\begin{array}{l}\text { Grace, } \\
\text { morality, } \\
\text { peace desired } \\
\text { restraint, } \\
\text { patience, } \\
\text { conviction, } \\
\text { dignity, } \\
\text { sincere } \\
\text { servitude, } \\
\text { living with } \\
\text { discipline, } \\
\text { freedom and } \\
\text { generosity. }\end{array}$ \\
\hline BRAVERY & $\begin{array}{l}\text { It is the result } \\
\text { of valor, } \\
\text { generosity, } \\
\text { sublime } \\
\text { volunteering, } \\
\text { courage and } \\
\text { righteousnes } \\
\text { s. }\end{array}$ & $\begin{array}{l}\text { Exquisite } \\
\text { greatness } \\
\text { (honor), } \\
\text { daring, large } \\
\text { have service, } \\
\text { perseverance, } \\
\text { patience, } \\
\text { gentleness, } \\
\text { to calmness, } \\
\text { courage and } \\
\text { boredom } \\
\text { folding. }\end{array}$ & $\begin{array}{l}\text { Exquisite } \\
\text { greatness } \\
\text { (honor), } \\
\text { courage, } \\
\text { supreme } \\
\text { purposefulness, } \\
\text { perseverance, } \\
\text { hilm, calmness, } \\
\text { daring, } \\
\text { endurance, } \\
\text { modesty, } \\
\text { maternity, } \\
\text { grace (rikkat). }\end{array}$ & $\begin{array}{l}\text { Willfulness } \\
\text { and maturity, } \\
\text { coping with } \\
\text { events, } \\
\text { zeal and ideal } \\
\text { glory, } \\
\text { tenacity, soft } \\
\text { temperament, } \\
\text { moderation, } \\
\text { self-well- } \\
\text { being and } \\
\text { devote to } \\
\text { good, endure, } \\
\text { modesty, } \\
\text { patronage } \\
\text { and humanity. }\end{array}$ \\
\hline JUSTICE & $\begin{array}{l}\text { When the } \\
\text { virtue of } \\
\text { thought, } \\
\text { virtue of } \\
\text { character, } \\
\text { valor, } \\
\text { moderation, } \\
\text { generosity, } \\
\text { sublime } \\
\text { willingness, } \\
\text { courage and } \\
\text { righteousnes }\end{array}$ & $\begin{array}{l}\text { Friendship, } \\
\text { affection, with } \\
\text { relatives } \\
\text { maintaining } \\
\text { relationships, } \\
\text { rewarding, } \\
\text { good } \\
\text { treatment, } \\
\text { something } \\
\text { beautifully } \\
\text { fulfill, love, }\end{array}$ & $\begin{array}{l}\text { Friendship } \\
\text { (loyalty), glory } \\
\text { (opinion of the } \\
\text { group and } \\
\text { unity in faith), } \\
\text { loyalty, } \\
\text { affection, } \\
\text { looking after } \\
\text { relatives, } \\
\text { reward } \\
\text { (kindness and }\end{array}$ & $\begin{array}{l}\text { Loyalty, } \\
\text { loyalty, } \\
\text { loyalty, } \\
\text { compassion, } \\
\text { my mother's } \\
\text { womb, } \\
\text { reward, in } \\
\text { joint affairs } \\
\text { honesty to } \\
\text { everyone } \\
\text { honesty, } \\
\text { relatives and }\end{array}$ \\
\hline
\end{tabular}




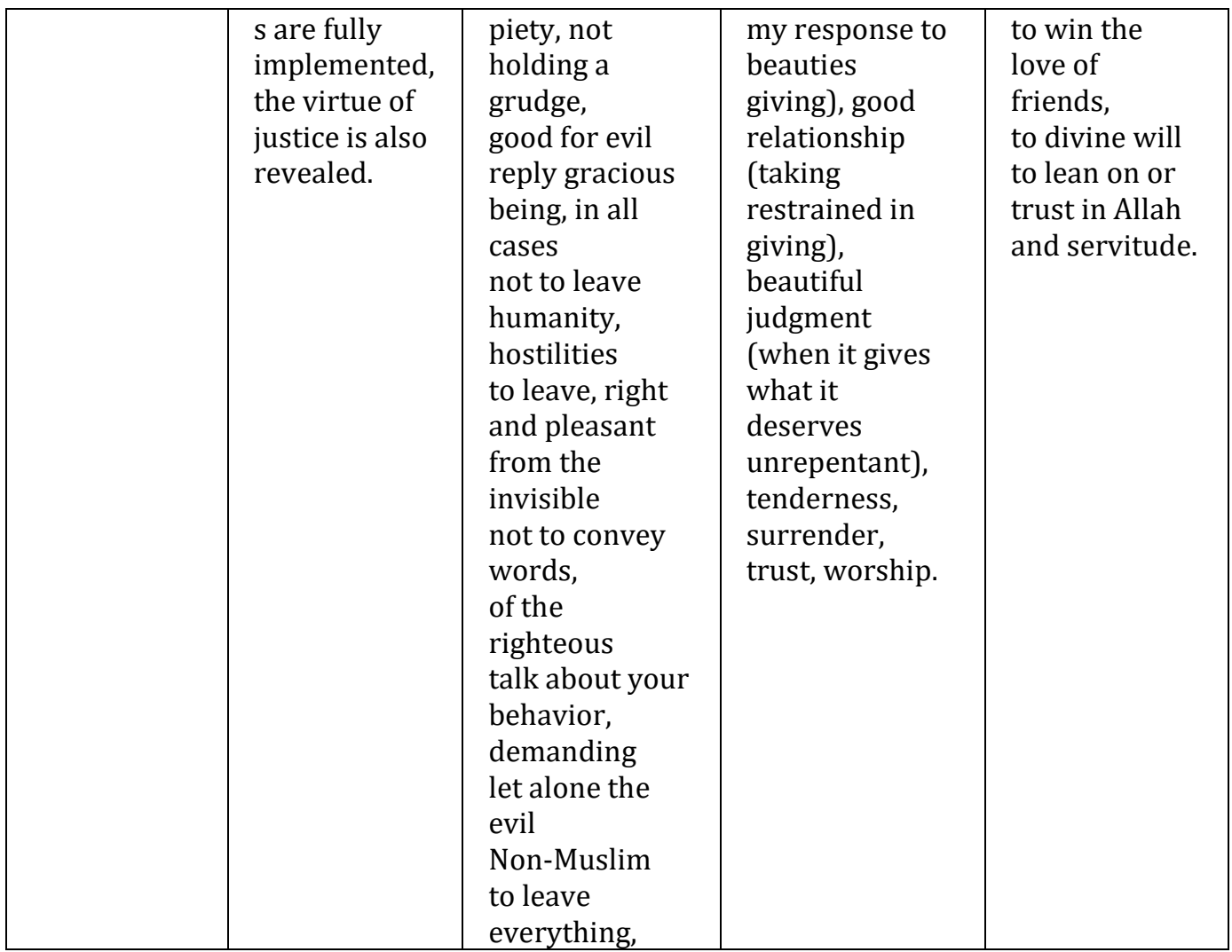

\section{Referrences}

[1] Aristotle, Ethics for Nicomachus, Translator: Zeki Özcan, Synthesis Publishers, Bursa, 2019.

[2] Cevizci, Ahmet, Introduction to Ethics, Paradigma Publications, İstanbul, 2002.

[3] Fahri, Macit, Islamic Ethical Theories, Translators: M. İskenderoğlu ve A. Arkan, Litera Publishers, İstanbul, 2004.

[4] Ibn Miskavayh, Ebu Ali Ahmad bin Muhmmed bin Yakub, Tahzibu'l Ahlak (Improving Morality), Translators: Abdülkadir Şener, Cihat Tunç \& İsmet Kayaoğlu, Büyüyen Ay (Growing Moon) Publishers, İstanbul, 2018.

[5] Ibn Miskavayh, Tahzibu'l Ahlak ve Tathiru'l Ahlak (Beautifying Morality and Cleansing Morality), Translators: Abdülkadir Şener, Cihat Tunç, İsmet Kayaoğlu; Büyüyen Ay Publications, İstanbul, 2018.

[6] Kaymakcan, Recep \& Meydan, Hasan; Ethics and Values Education, Dem Publications, İstanbul, 2014.

[7] Kinalizada Ali Efendi, Ahlak-ı Alai (The Highest Morality), Translator: Mustafa Koç, Klasik Yayınları, İstanbul, 2017. 
[8] Nasiruddin Tusi, Ahlak-ı Nasıri, Translators: Anar Cafarov \& Zaur Şükürov, Litera Publishers, İstanbul, 2016.

[9] Pazarlı, Osman; Morality in Islam , The Bookstore of Remzi Publicaitons, İstanbul, 1980.

[10] Plato, The State, Translator: Ersin Uysal, Dergah Publications, İstanbul, 2005. 